\title{
SOME ASPECTS OF NONLINEAR MECHANICS IN CALCULATIONS OF REINFORCED CONCRETE
}

\section{ДЕЯКІ АСПЕКТИ НЕЛІНІЙНОЇ МЕХАНІКИ У РОЗРАХУНКАХ ЗАЛІЗОБЕТОНУ}

\author{
Palyvoda O.A., Ph.D. in Engineering (Kryvyi Rih National University, \\ Kryvyi Rih)
}

Паливода О.А., к.т.н. (Криворізький національний університет, м. Кривий Ріг)

Abstract. The results of experimental studies of concrete at different levels of compression stresses loaded in young and middle age are presented. The questions of the expediency of taking into account nonlinear relative creep deformations in practical calculations are considered. The processing of experimental data is done, conclusions are made.

Анотація. Постановка мети і задач дослідження. Метою поставлених досліджень було наступне: провести аналіз даних, отриманих під час дослідження бетонних елементів, завантажених в молодому та середньому віці, на дію тривалих навантажень; 3'ясувати особливості нелінійних деформацій повзучості, які виникають при низькому рівні напружень та для всіх його рівнів. Методика досліджень. 3 огляду на означену мету, було проаналізовано експериментальні дані отримані дослідниками, які в різний час займалися питаннями вивчення нелінійності деформацій повзучості при тривалій дії навантаження. Експериментальні дані були узагальнено та проведено їх обробку. Результати досліджень. На підставі дослідних даних було побудовано криві питомих, тобто віднесених до одиниці напружень, деформацій повзучості при різних рівнях відносних напружень в зразках. При цьому нелінійність спостерігається для бетонів різного віку на момент навантаження. Чіткої межі лінійної повзучості бетону провести не можливо; ймовірно, навіть при низьких рівнях напружень стискання в мікроструктурі бетону мають місце певні 
порушення або пластичні зсуви, які спричиняють нелінійність його деформацій повзучості. Аналіз графіків дозволяє стверджувати, що криві питомих деформацій повзучості істотно відрізняються за величиною ординат, починаючи з самого низького рівня напружень. Також слід відмітити, що ступінь нелінійності деформацій повзучості особливо великий в моменти часу, близькі до початку завантаження зразків. Про те, що нелінійність деформацій повзучості насамперед пов'язана 3 процесами, які відбуваються в бетонному зразку безпосередньо після його завантаження, говорить i значна різниця у величинах деформацій, що натікають за час витримки при навантаженні зразка до заданого рівня напружень. Якщо ці деформації не включати у величину деформацій повзучості, то ступінь нелінійності останніх значно знизиться. Загальний аналіз числових значень деформацій повзучості дозволяє зробити висновок, що швидко напливаючі деформації можуть складати значну долю (до 20...26\%) деформацій повзучості. Не враховувати їх неприпустимо, оскільки це може призвести до суттєвих неточностей при розрахунку конструкцій на тривалі впливи. Також можна говорити про те, що відносні деформації повзучості бетонів, завантажених в молодому та середньому віці при різних рівнях стискаючих напружень, не являються мірою повзучості. Таким чином в найбільш розповсюджених випадках лінійної повзучості практично не існує.

Keywords: calculation of reinforced concrete; physical nonlinearity; the theory of concrete creep; elastic-plastic deformation.

Ключові слова: розрахунок залізобетону; фізична нелінійність; теорія повзучості бетону; пружно-пластичні деформації.

Introduction. Modern theory of calculations of building structures, including normative models, is mostly based on three sections of construction mechanics: linear mechanics, nonlinear mechanics, theory of creep.

Navier's principle of slowness of displacement, which is used in conjunction with Hooke's law, has created methods of linear theory. The replacement of Hooke's law by nonlinear dependencies between stresses and deformations leads to the consideration of physical nonlinearity in the theory of nonlinear elasticity and the theory of plasticity. General methods of calculation in the conditions of physical nonlinearity are not 
developed enough. Long-term deformation of concrete with nonlinear creep has not been studied. Especially poorly studied the character of the nonlinearity of creep deformation of young concrete and the degree of nonlinearity of these deformations in the zone of low compressive stresses.

Consequently, in the norms of some countries only declarative considerations about the possibility of calculation, taking into account physical nonlinearity, are indicated.

Analysis of recent research. The theory of creep of concrete has a significant impact on the calculations of long-term resistance of reinforced concrete structures. The creep of concrete and reinforced concrete structures have been studied in fundamental works of Yu. Rabotnov, N. Harutiunian, A. Gvozdiev, R. Davis, V. Glennville, P. Vasyliev, S. Aleksandrovskyi, I. Porokopovych, S. Ulitskyi, L. Kachanov, V. Bondarenko, A. Rzhanitsyn, A. Freudenthal and other scientists.

In the modern theory of concrete creep there are several models different in terms of design and use in real calculations.

First of all, this is the nonlinear creep theory of N. Harutyunyan [1] with instantaneous linear properties, which is used in calculations of reinforced concrete structures. The disadvantages of this theory include the fact that it almost erases the effect of stresses that act directly before the time of observing deformations. This theory does not reflect the rapid flow of creep deformations up to the time of observation, which is close to the moment of loading of the samples, which is observed in the experiments. The initial sections of the creep curves which are constructed based on the theory of $\mathrm{N}$. Harutyunyan, do not have a characteristic upward-growing shape which is observed in experiments not only on the young, but also on the old concrete. At the same time, there are claims that it is unacceptable for solving problems with rapidly changing processes in time.

A. Yashin proposed the measure of creep of concrete, which combines the features of the heredity theory and the aging theory of concrete, and thus corrected the disadvantages of the creep degree of $\mathrm{N}$. Harutyunyan [1]. Unfortunately, A. Yashin's model has not received sufficient development due to ambiguous evaluation. The disadvantages were the complexity, as well as the fact that built on its basis integral equations of creep cannot be brought to the corresponding differential equations. 
N. Katin complicated A. Yashin's model complementing it with a singular function similar to the A. Freudenthal function.

I. Prokopovych and I. Ulitskyi simplified A. Yashin's model of concrete creep. This simplified model was successfully used in integral form by E. Yatsenko to solve some practical problems.

S. Aleksandrovsky and his students within the framework of instantly spring material and N. Harutyunyan's hypotheses have built the integral equations of nonlinear creep that take into account the phenomena of rapid creep.

European standards only take into account the ultimate creep characteristic of concrete; in the calculations, it is additionally multiplied by the ratio of the levels of short-term and additional load. In this creep model, concrete is considered to be elastic, thus, it works indefinitely in tension and compression. The numerical characteristics of this model, obtained for the case of the central compression of a concrete rod, are applied to other cases of the work of compressed-curved reinforced concrete elements. The proximity of this approach implemented with a long-term load differs significantly from the strict deformation model underlying the calculation of the short-term load of reinforced concrete. At the same time, it should be pointed out that the results of calculations for the long-term load of columns in European codes provide a safety margin of the bearing capacity, the value of which is in no way evaluated [2].

It is necessary to pay attention to the problem of taking into account the time factor in the calculations of reinforced concrete structures. To solve it, the equations of plasticity and creep must be used together. Many modern creep theories do not satisfy this requirement, since they use Hooke's law for instantaneous deformations and not a curvilinear relation, which is an analytical record of the curvilinear diagram $\sigma-\varepsilon$ for concrete with a downward branch [3]:

$$
\sigma=(a \varepsilon) \cdot\left(\frac{b+c \varepsilon}{d+c \varepsilon}\right),
$$

where $a, b, c, d$-empirical coefficients.

To describe the creep of bodies that are not aging and bodies loaded in the old age the theory of elastic heredity is used which was developed in the papers of Yu. Rabotnov, A. Rzhanitsin, A. Malmeister, A. Skudria and other scholars. This theory of creep, additional assumptions about 
the value constancy for the aging function are adopted, as well as the constancy of the elastic modulus:

$$
E(\tau)=E_{0}=\text { const },
$$

It should be noted that the theory of elastic-creeping body describes the partial inversion of the creep deformation.

But the theory of the elastic heredity ignores the process of concrete aging and consequently the whole deformation of creep turns out to be inverse.

In the linear theory of creep created specifically for the calculation of concrete and reinforced concrete structures, which is called the theory of aging, an additional hypothesis about the parallelism of the creep curves is used. The latter allows us to obtain the creep curve of concrete loaded at the age $\tau$ from the creep curve of concrete loaded at an early age:

$$
\begin{gathered}
C(t, \tau)=C(t)-C(\tau), \text { or } \\
C(t, \tau)=C(t)-C(\tau), \frac{1}{E(0)} \cdot[\varphi(t)-\varphi(\tau)],
\end{gathered}
$$

where $\varphi(t), \varphi(\tau)$ - the creep characteristic which is approximated by a certain curve.

Theoretically, formula (3) means that the creep curves of various concrete samples loaded with the same stress $\sigma$, but at different points in time, coincide with all points as they gradually move vertically (along the axis of deformations). This property of parallelism introduces simplifications in the calculations of reinforced concrete structures for creep. It should also be noted that the hypothesis of parallel creep curves leads to complete irreversibility of creep deformations.

In the nonlinear theory of creep [4] an additional hypothesis is used about the existence of an affine similarity of the curves of simple creep deformations corresponding to the stresses of different levels:

$$
\varepsilon_{\Pi}\left(\sigma, t, \tau_{i}\right)=f(\sigma) \cdot C\left(t, \tau_{i}\right),
$$

where $\varepsilon_{\Pi}\left(\sigma, t, \tau_{i}\right)$ - deformation of the concrete creep loaded with stress $\sigma$

$f(\sigma)$ - certain nonlinear function, which is called a stress function; $C\left(t, \tau_{i}\right)$ - the value of the creep deformation at the specific load in the concrete (the degree of creep). 
The hypothesis (4) means that the creep deformation curve caused by the stress $\sigma$ can be obtained by multiplying the ordinates of the creep deformation curve caused by the specific stress by a certain stress function.

The analysis of the above mentioned suggests that the nonlinear creep of concrete is studied insufficiently both experimentally and theoretically. Existing theories, in more detail, are very controversial and not very suitable for practical calculations.

The purpose and objectives of the study. The aim of the research was the following: to analyse the data obtained during the study of concrete elements loaded at young and middle age, to the effect of longterm loads; find out the features of nonlinear creep deformations that occur at low stress levels and for all its levels.

Research methodology. Taking into account the stated purpose, the experimental data obtained from the researchers [5 ... 7], who at various times engaged in the study of nonlinearity of creep deformations under prolonged load were analysed. Experimental data were summarized and processed.

Research results. Based on the experimental data, the curves of specific stresses and creep deformations were constructed at various levels of relative stresses in the samples (Fig. 1).

In Figure 1, the nonlinear dependence of creep deformations on the operating constant stresses is clearly observed, starting from the smallest level $\sigma=0,09 \mathrm{R}_{\text {пр }}$; at the same time nonlinearity is observed for concretes of different age at the time of loading. A clear boundary of the linear creep of concrete is impossible to draw; probably, even at low levels of compression stresses, certain disturbances or plastic shifts occur in the microstructure of concrete, which cause the nonlinearity of its creep deformations. Therefore, it is more expedient to speak only of the conventional boundary of the linear creep of concrete followed by a zone of a high degree of nonlinearity.

The analysis of Figure 1a allows us to assert that the curves of specific creep deformations differ significantly in magnitude of ordinates, starting with the lowest level of stress. It should also be noted that the degree of nonlinearity of creep deformations is particularly large at moments of time close to the start of loading samples. After some time, the curves of specific deformations become almost parallel, that is, the increase of creep deformations begins to linearly depend on the operating stresses. But still the initial nonlinearity of deformations 
continues to significantly affect the magnitudes of the ordinates of the creep curves throughout the observation period.
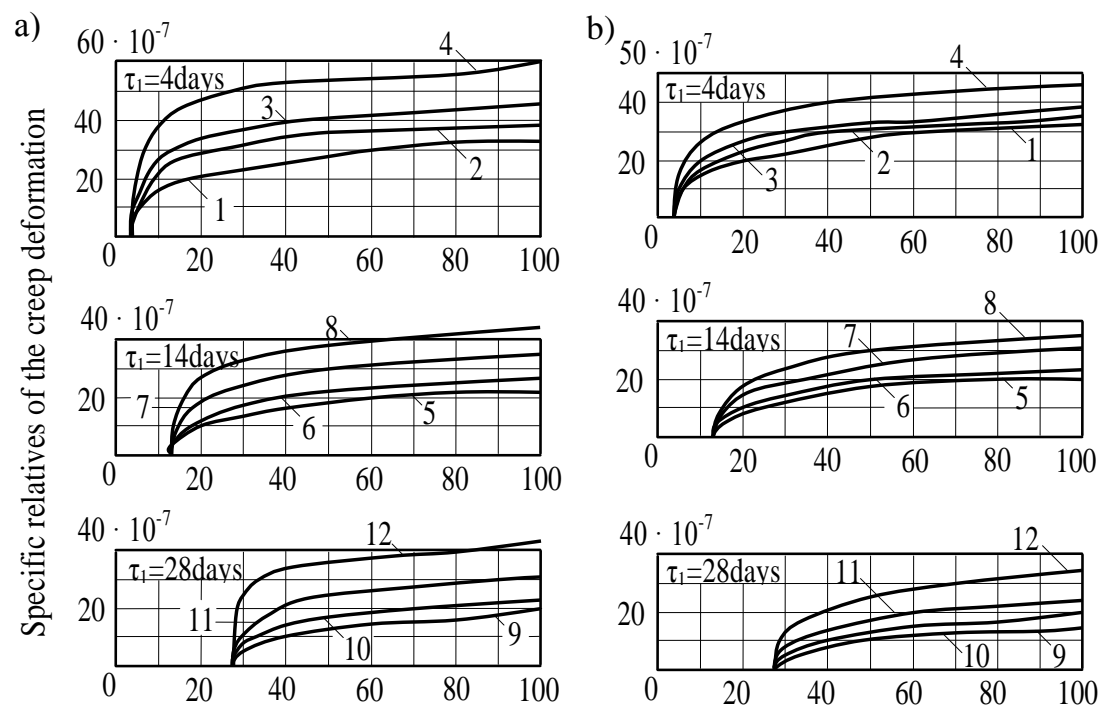

The concrete age at the time of observation, days

Figure 1. Experimental curves of specific creep deformations at different levels of constant compression stresses taking into account (a) and without taking into account (b) deformations occurring during the exposure time during loading:

$\tau_{1}=4$ days: $1-\sigma=0.09 R_{\text {пр }} ; 2-\sigma=0.29 R_{\text {пр }} ; 3-\sigma=0.49 R_{\text {пр }} ; 4-\sigma=0.77 R_{\text {пр }}$, $\tau_{1}=14$ days: $5-\sigma=0.10 R_{\text {пр }} ; 6-\sigma=0.29 R_{\text {пр }} ; 7-\sigma=0.48 R_{\text {пр }} ; 8-\sigma=0.72 R_{\text {пр }}$, $\tau_{1}=28$ days: $9-\sigma=0.10 R_{\text {пр }} ; 10-\sigma=0.31 R_{\text {пр }} ; 11-\sigma=0.52 R_{\text {пр }} ; 12-\sigma=0.73 R_{\text {пр }}$.

The fact that the nonlinearity of creep deformations is primarily associated with processes occurring in a concrete sample immediately after loading, is proved by the significant difference in the values of deformations occurring during the exposure time when the sample is loaded to a predetermined level of stress (Fig. 2a) If these deformations are not included in the magnitude of the creep deformations, then the degree of nonlinearity of the latter will significantly decrease (Fig. 2b). The curves of specific creep deformations in Figure $2 b$ for each age of concrete before loading by magnitude of ordinates differ less than in figure $2 \mathrm{a}$. 
Probably, the ignoring of fast-flowing deformations is one of the reasons that the nonlinearity of creep deformations at low levels of

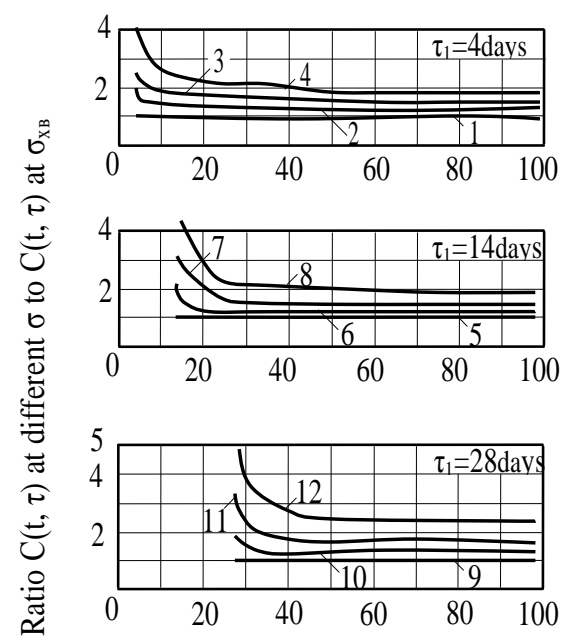

The concrete age at the time of observation, day

Figure 2. Curves of changes in the ratio of specific creep deformations at different levels of constant stresses to the creep curve obtained at $\sigma / R_{\text {пр }} \approx 0.1$. Notations are the same as in Fig. 1. compression stresses was previously neglected. It should also be taken into account that the deformations that emerge during the exposure time during loading were not artificially pressed by the test loads, as it usually happens when centering prisms along the physical center.

The idea of the degree and nature of nonlinearity of creep is given in Fig. 2. The form of these curves, as in the works of other researchers, suggests that the degree of nonlinearity of creep deformations significantly depends on the duration of the observation $(\mathrm{t}-\tau)$, and accordingly the curves of specific creep deformations do not have affine similarity. This is evidenced by the parallelism of the curves shown in Fig. 1a, since parallel creep curves cannot be affine, that is, they cannot be obtained one from the other by multiplying by a constant factor if the ordinates have not reached the limit values. The last observation introduces restrictions on the application of this hypothesis and its analytical record (4) when solving a certain range of problems of the nonlinear theory of concrete creep.

Conclusions. The analysis of the numerical values of the creep deformation allows us to conclude that fast-flowing deformations can account for a significant fraction (up to $20 \ldots$ 26\%) of creep deformations. Failure to take them into account is unacceptable, as this may lead to significant inaccuracies in the calculation of structures for 
long-term effects, for example, in determining the losses of the previous tension in the reinforcement.

It can also be said that the relative creep deformations of concrete loaded in young and middle aged at different levels of compressive stress are not a measure of creep. Thus in the most widespread cases, linear creep is practically non-existent. The adoption of a linear relationship between stress and creep deformation at low stress levels is very conditional and quite often is not appropriate.

\section{REFERENCES}

1. Арутюнян Н. Х. Некоторые вопросы теории ползучести. М., Л. : Гостехтеориздат, 1952. 327 c. [Arutiunian N. Kh. Some questions of the theory of creep. Moskow, Leningrad, 1952. 327 р.] 2. Беглов А.Д., Санжаровский Р.С., Бондаренко В.М. Ползучесть бетона и модели Евростандартов. Бетон и железобетон. 2005. № 2. C. 29-30. [Beglov A.D., Sanzharovskiy P.S., Bondarenko V.M. Creep concrete and European standard models. Concrete and reinforced concrete. 2005. № 2. P. 29-30.] 3. Sargin M. Stress-strain relations hips for concrete and the analysis of structural concrete sections. SM Study, Solid Mechanics Division, University of Waterloo, Ontario, Canada, 1971. № 4 Р. 114-119. $\quad$ 4. Васильев П.И. Связь между напряжениями и деформациями в бетоне при сжатии с учётом времени. Известия ВНИИГ. 1951. Т. 45. С. 78-92. [Vasiliev P.I. The relationship between stresses and deformations in concrete in compression with time. News of All-Russian Research Institute of Hydraulic Engineering. 1951. issue 45. P. 78-92.] 5. Мамуров М.М. Нелинейная ползучесть железобетонных стержневых конструкций: дисс. ... канд. техн. наук : 05.23 .17 / Ленинградск. инженерно-строит. инст-т. Ленинград. 1983, 179 с. [Mamurov M.M. Nonlinear creep of reinforced concrete core structures : Diss. Ph.D / Leningrad Institute of Civil Engineering. 1983, 179 p.] 6. Мельник P.A. Экспериментальные исследования нелинейной ползучести бетона. Сборник научных трудов КИСИ. 1961. Вип. 16. С. 38- 43. [Melnyk R.A. Experimental studies of nonlinear creep concrete. Collection of scientific papers of the Kiev Institute of Civil Engineering. 1961. issue 16. P. 38-43.] 7. Мухамедиев Т.А. Методы расчёта статически неопределимых железобетонных стержневых и плоскостных конструкций с учётом нелинейных диаграмм деформирования материалов и режимов нагружения: дисс. ... докт. техн. наук: 05.23.01 / НИИЖБ. Москва. 1990, 343 c. [Mukhamediev T.A. Methods for calculating statically indeterminate reinforced concrete bar and plane structures with regard to non-linear material deformation diagrams and loading modes: Diss. Doct. Techn. Sc. / Research, Design and Technological Institute of Concrete and Reinforced Concrete. Moskow, 1990, 343 p.] 